\title{
BELGIUM AND OFFICIAL COOPERATION WITH ZIMBABWE
}

\author{
Robrecht RENARD \\ Development Cooperation \\ WTC Tower 2 \\ Em. Jacqmainlaan 162
}

The title and the timing of my introduction might create an impression in the audience that Belgian development assistance to Zimbabwe is something very substantial or, if not, that we plan to raise the levels of ODA to Zimbabwe to something substantial in the near future.

In fact, neither of those is the case. Belgian ODA to Zimbabwe is very modest, even in Belgian terms, and we are not planning any dramatic changes in the near future.

I will briefly review what we have been doing over the last 10 years in terms of development assistance and then say something about the plans for the future. A future which has to be seen essentially in a SADCC context.

There is no formal cooperation agreement with Zimbabwe. There is a kind of memorandum of understanding, which is a technical document regulating import of equipment in the framework of technical assistance.

In March 1981, during the ZIMCORD Conference, the Minister of Development Cooperation, Mr. Coens, committed BEF 300 million during the Three-Year Transitional Development Plan period. This was on a grant basis, to be used for technical assistance and projects. In addition to that there was a provision for soft, state-to-state loans. 
If we look at the actual implementation, I think the comments of Mrs. Walraet were very apt, i.e. that we are better at promising than at implementing our programs. On average, in the period 1981-88, the Belgian ODA to Zimbabwe reached BEF 38,7 million, or just over US \$ 1 million, per year. Of that, about BEF 30,5 million was from the Ministry of Cooperation, that is the Belgian Administration for Development Cooperation (BADC), the rest from the Ministry of Finance. That is together about BEF 300 million, of which roughly BEF 250 million from BADC. The state-to-state loan component, as indicated by someone in the audience, has never been fully utilised. Roughly BEF 100 million was utilised right in the beginning of 1981 for the import of electrical equipment for locomotives. As far as the BADC component is concerned, the big year was 1986, when BEF 70 million shows up in the statistics of the Belgian ODA to Zimbabwe.

Looking more closely at the BADC assistance to Zimbabwe, I am struck by the fact that on the one hand it is very fluctuating from year to year and secondly that the share of what we call indirect aid has always been high and is on the increase.

This is a technical concept and a Belgian concept that I may have to explain a little bit. Indirect aid is every form of aid which is not negotiated on a government-togovernment basis. It involves on the one hand multilateral aid and on the other hand aid to Belgian NGOs, universities, other organisations like VVOB, that is organisations that have a project in Zimbabwe and come directly to the Belgian government for subsidies. This share of indirect aid, and I exclude from this the multilateral aid, was about $40 \%$ in 1983 and now stands at $72 \%$. So the vast majority of our aid to Zimbabwe is in the form of indirect aid, and has been increasing consistently over time, both in absolute value and as a share of total aid to Zimbabwe.

To give you some figures on this: there are about 40 volunteers working in $\mathrm{Zim}$ babwe. In terms of NGO projects, the amounts move erratically up and down from year to year. VVOB started a program of technical assistance in 1988, and there are two university initiatives.

Before saying what our present attitude is towards Zimbabwe, I have to make two excursions. One is into the general problem of the disbursion of Belgian aid and the other one is into the SADCC.

The first problem anyone working on Belgian aid policies will face, is the immense dispersion of Belgian bilateral aid. For what amounts to a small overall program about US \$ 600 million in 1988 - is disbursed among 46 countries. This means we negotiate projects from government to government in 46 countries. In addition we have 70 more countries where we have only indirect aid. In those 46 countries we 
have sometimes general conventions, this is the case in 26 countries. This is very much in relation to the volume of our aid budget. If you compare e.g. with the Netherlands, with a budget about three times as large, they have only 10 concentration, what they call programme, countries, plus Surinam, plus four regional areas, like the Sahel and Southern Africa. In contrast, we have almost 50 countries where we have direct aid. One of our ambitions is to reduce the number of countries where we have bilateral direct relations. The aim is thus to increase the effectiveness and efficiency of the Belgian development programme.

The second excursion concerns the SADCC. Up to last year, Belgian involvement in SADCC countries was on a purely bilateral basis. At the annual conference in Luanda in February 1989, Minister Geens made the announcement that henceforth our involvement would be also on a regional basis. The BEF 600 million direct aid Mrs Walraet talked about, are meant to be additional to what continues to be done with the different countries in the form of indirect aid. The indirect aid doesn't come under the BEF 600 million, but as far as direct aid is concerned, we plan to gradually bring all of it under this heading. In the past, Zambia and Tanzania were the two SADCC countries where we were most involved. Sectorwise, we were most involved in transport, especially railways, and somewhat less in agriculture and health. In the intervening year since the Luanda conference, we had long discussions with our administration about how to implement the first part of the BEF 600 million programme and I hope that in a very near future we'll come to a final decision on that. We are trying to force the administration to come forward with a complete and coherent plan rather than provide projects on an individual basis. The SADCC region will be considered as a concentration region. That means that countries like Zimbabwe or Zambia will not be receiving direct bilateral aid on a pure bilateral basis, but always within an SADCC framework. In the execution stage, almost all SADCC projects become bilateral projects. The SADCC label therefore essentially applies at the project selection stage.

This brings me to our policy options as far as Zimbabwe is concerned. Two years ago, it was not very clear whether Zimbabwe was yes or no a priority country. It ranked about the 30 th in our list of countries receiving direct bilateral aid. It had no formal cooperation agreement but there were discussions on whether it should get one or not. I personally have been advising the minister - and what I will say will not make me be popular in this audience - not to select Zimbabwe as a concentration country for the reasons that I have explained: we have an enormous need to reduce the dispersion of Belgian bilateral aid. At the same time we have embarked on this concept of regional concentration, and as the SADCC is the first region which we handle under this concept, there is a budget for the whole region. We have a development section in one country of the region to serve the whole region and in Brussels we have a regional desk rather than a country desk at the administration. 
This means specifically that all direct aid to Zimbabwe will fall under the SADCC system, i.e. Zimbabwe will have to propose projects to us, which have been screened by the SADCC. Exceptions to that are certain forms of financial aid, which are very easily administrated from Belgium, and all forms of indirect aid, which at present are in fact dominant in our relations with Zimbabwe. The next element is that we have set up the regional cooperation section for the SADCC right there in Harare. We have not selected Gabarone for purely pragmatic reasons: Harare is a better place to reach most SADCC countries than is Gabarone. Our regional concept, although it is very much focussed on the SADCC, is somewhat broader than just the SADCC. We don't know what the evolution will be in the SADCC region within the next years, but whatever happens, it will be good to have a regional focus on Southern Africa and to handle that from Harare.

Our opinion on the SADCC is very similar to some of the opinions we have heard during the discussion.

The SADCC has been certainly a success. In the first place as a development lobby for the countries involved. In the second place, as a forum for the member countries to talk to each other and to exchange information, and to set up joint projects.

We like the SADCC for very pragmatic reasons. We think that one advantage has been that the SADCC itself has been very pragmatic up to now. We'll see how it evolves but we feel that our decision to take a regional approach to Southern Africa, will survive even if the SADCC as an institution would run out of steam.

Zimbabwe is a very interesting country and we would love to have it as a country where eventually we could give more assistance, but the overall size of the Belgian development budget being what it is, it would be unwise to try to spread out that aid too thinly.

To end, I would like to give some brief replies to some of the comments made regarding our SADCC and Zimbabwe policies.

As I already said, the BEF 600 million is intended to be additional, as far as direct aid is concerned.

The point about the implementation lag is well taken. I think it is a correct criticism.

Personally I also agree with the criticism about the tying of aid. I invite you people at the universities to renew the analysis of that aspect and to try to show that in certain 
instances, tied aid can be very detrimental to development. At the same time, on a very pragmatic basis, I find that the fact that aid has to be tied according to certain procedures in Belgium, need not be to be so dramatic. I think there are many ways of reducing the potential damage that it can cause.

As far as the point is concerned of the SADCC trying to set up its own productive capacity and whether Belgium is prepared to assist in that effort, the answer is yes, on a very pragmatic basis. We are waiting for another year to commit the last part of those BEF 600 million and we are looking for studies, among them, a study from Ghent University, in order to make up our mind. But we want to be very non-ideological in this. Regional cooperation is a very beautiful idea in theory but works usually very badly in practice. That at least is unfortunately the general experience in developing countries. We do not want to invest in ideas that do not work, but if viable projects are on the table we will consider them.

I thank you for your attention. 
Every issue of AFRICA FOCUS provides in the AFRICA REVIEW a survey of one or two African Countries. The choice is related, if possible, to articles published in the issue.

The survey of the following countries has already been published :

ANGOLA in Vol. 4, 1988, nr. 3-4

BENIN in Vol. 5, 1989, nr. 1-2

BOTSWANA in Vol. 6, 1990, nr. 2

LIBERIA in Vol. 4, 1988, nr. 1-2

LIBYA in Vol. 4, 1988, nr. 3-4

MADAGASCAR in Vol. 6, 1990, nr. 1

MALI in Vol. 5, 1989, nr. 3-4

MOROCCO in Vol. 6, 1990, nr. 2

NIGERIA in Vol. 5, 1989, nr. 3-4

RWANDA in Vol. 6, 1990, nr. 1

SOUTH-AFRICA in Vol. 5, 1989, nr. 1-2

TOGO in Vol. 4, 1988, nr. 1-2

ZAIRE in Vol. 4, 1988, nr. 1-2

ZIMBABWE in Vol. 6, 1990, nr. 3-4 